\title{
GCG, ROE and Size on CSR Based on Sharia Enterprises Theory
}

\section{Dwi Nita Aryani" Imama Zuchroh²}

\begin{abstract}
The purposes of this paper are to investigate the Corporate Social Responsibility (CSR) reporting information at Indonesia sharia banks based on Sharia Enterprise Theory and explores the potential effects of Corporate Governance (CG) elements, Return on Equity (ROE) on CSR based on sharia enterprises theory, with size as the moderating variable. Using the sample of 10 sharia banks which published annual reports, CG, and CSR reports above the year 2014 to 2016, the panel data are examined by regression. The statistic test reveals that size is not fit as a moderating variable in testing the effect of CG and ROE on CSR. Aggregately, GCG, Size and ROE influence CSR. Large and high-profit sharia banks which apply good corporate governance will implement CSR by considering horizontal and vertical accountability based on Sharia Enterprise theory. This study makes a significant contribution to the Corporate Social Responsibility (CSR) and enterprise theory by offering Sharia Enterprise theory as the foundation of the CSR implementation at sharia banks.
\end{abstract}

Keywords: Sharia Enterprise Theory, CSR, GCG, ROE, Size

\begin{abstract}
Abstrak. Tujuan penelitian ini untuk mengetahui sejauh mana penerapan CSR pada bank syariah berdasar Sharia Enterprise Theory, dan menguji pengaruh GCG, ROE terhadap CSR dengan Size sebagai mode ratingnya. Sampel penelitian yang digunakan adalah 10 bank syariah yang menerbitkan laporan tahunan pada tahun 2014-2016, dan panel datanya diuji dengan regresi. Hasil penelitian mengungkapkan bahwa size tidak memoderasi pengaruh GCG dan ROE terhadap CSR. GCG, ROE dan size secara bersama-sama mempengaruhi CSR. Bank syariah yang besar dan mempunyai laba yang tinggi serta menerapkan corporate governance dengan baik akan mempengaruhi bagaimana penerapan CSRnya dengan lebih memperhatikan hubungan horizontal maupun vertikal yang sesuai dengan Sharia Enterprise Theory. Penelitian ini memberikan kontribusi pada penerapan CSR dan enterprise teori terkait dengan pelaksanaan CSR yang mendasarkan pada Sharia Enterprise theory pada bank syariah.
\end{abstract}

Kata kunci: Sharia Enterprise Theory, CSR, GCG, ROE, Size

\footnotetext{
${ }^{1}$ Management Dept., STIE Malangkucecwara, Malang, Indonesia | dwinita@stie-mce.ac.id

2 Management Dept., STIE Malangkucecwara, Malang, Indonesia | imama_zuchroh@yahoo.com
} 


\section{Introduction}

Implementation of Corporate Governance (CG) nowadays is one of mandatory regulations for company in order to direct and manage the company toward business growth and company accountability. Since economic crisis in 1998, implementation of CG in Indonesia started became more important. More companies are trying to improve its CG, when they concern on company sustainability. To keep sustainability of the firms, companies should not merely consider achieving profit, but they should also pay attention on a triple bottom line concept. Elkington (1998) asserted that a triple bottom line namely People, Planet and Profit as a pilar for measuring the succesful of company with three cryterias i.e economics, environment, and social. The concept of triple bottom line underlines that company should be more concern to prosper the wealth of their stakeholders than shareholders. Furthermore, implementation of CG is also trusted which is able to control the company manager behavior. They should not only taking profit for themselves, but also consider to synchronise between shareholders, managers and stakeholders' interests.

Five principles which must be implemented in CG are Transparency, Accountability, Responsibility, Integrity, and Fairness. The principle of accountability requires companies to comply with legislation and carry out responsibility to society and the environment in order to maintain long-term sustainability of the business. Implementation of Good Corporate Government (GCG) dives direct implications for the extent of corporate social responsibility disclosure. Social responsibility is an accountability of the company to all parties who are interested in the company. Activities undertaken related to social, economic and environmental aspects CSR can be a part of CG due to in the principle of responsibility, a company must be obey regulations and also responsible to stakeholders including the society and environment. Implementing CSR also means that a company concern on one of the triple bottom line i.e planet or environment. This is in line with 
Enterprise Theory which states that responsibility is not only to the shareholders but also stakeholders, even wider to the society and environment. This is also adreessed by Republic of Indonesia company Law number $40 / 2007$ on chapter $\mathrm{V}$ article number 66 and 74 that limited liability companies are obligated to do social and environment responsibility.

Corporate Social Responsibility is a kind of action for communicating with stakeholders to show that companies already paid attention on environment, nature and society. Nevertheless, the concept of CSR has not been perfect when managers did not responsible to the creator of nature. The most appropriate theory in explaining of corporate social responsibility according to Meutia and Febrianti (2017) is Sharia Enterprise Theory (SET). In the Sharia Enterprise Theory (SET), Triyuwono (2007) explained that companies should not only responsible on the horizontal accountability namely to stakeholders and environment, but they must responsible on the vertical accountability i.e to the God, Allah SWT, as the highest party and the only one of human life aim. However, a study conducted by Mansur (2012) found that implementation fo CSR on sharia banks was still limited, voluntarily, and has not complied with SET. Furthermore, Erwanda and Mulawarman (2012) mentioned that sharia bank has implemented CSR yet only concerned in social aspect such as education, meanwhile economics and environment have not be applied and this did not fit with SET.

Law Number 21 of 2008 concerning sharia banking, article 4 states that Sharia Bank and Sharia Business Unit have a social function as the form of baitul mal institution, which receives zakat, infaq, alms, grants or other social funds and distributes it to the zakat management organization. Moreover, sharia bank and SBU can also collect social funds from wakaf funds and distribute it to the wakaf (nadzir) manager in accordance with wakif (Wiroso, 2009). The existence of this social function means that indirectly sharia banks have already done corporate social responsibility (CSR) even in line with SET.

Research to test correlation between GCG and CSR have been done by previous researcher, however they employed conventional companies and a 
very few research used sharia bank as the object and fit with SET perspective when they implemented CSR. Farook and Lanis (2007) also asserted that a very little sharia banks and financial institution concern to social activities. Farooq, Ullah, and Kimani (2015) mentioned that larger firms have more capital than small companies, hence they are more capable and unimpeded to invest in corporate social responsibility (CSR). Furthermore, there is a positive association between GCG and CSR with size and profitability as control variables (Jo and Harjoto, 2011). Moreover, Furtado, Araújo, and Moreira (2016) argued that company size has a positive relationship with CSR disclosure. Maryanti and Tjahjadi (2013) found that CSR and GCG affect ROE, meanwhile GCG influenced CSR, and size moderates the correlation between CSR and ROE. Nevertheless, Aryani (2012) asserted that GCG through ROE affected CSR. On the other hand, Mozghovyi and Ratnykova (2011) found unclear relationship between CSR and company financial performance (ROE). A research by Khan, Muttakin, and Siddiqui (2013) asserted that CSR and manager ownership has a negative association. They also could not find impact of CEO's role on CSR disclosures.

Even though many research tested the relationship between CG and ROE on CSR and have mixed results, up to now, there is no previous research tested the impact of GCG and ROE on CSR based on Sharia Enterprise Theory perspective with size as moderating variable. Furthermore, the influence of corporate governance mechanisms on CSR may have different results in emerging market.

Based on the explanation above, the aims of this study are first, to analyse the effect of GCG and ROE on CSR. Second, to test the effect of GCG and ROE on CSR based on Sharia Enterprise Theory with size as the moderating variable in sharia banks in Indonesia.

\section{Literature Review}

A relationship between agents and principals leads to conflicts. The conflict between principals and agent can be explained in agency theory. 
Jensen and Meckling (1976) asserted that the relationship between agents (companies) and principals (stakeholders) can generate agency conflict, due to conflicting of interest between those parties. Agency problems appear because there are different desires between two parties or among participants who have collaboration, for example the managers and employees, banks with community, debtors and creditors, or managers and shareholders. Jensen and Meckling (1976) argued that the difference of interest between agents and principals is able to trigger agency problems because managers will execute their jobs for their own interest and benefit, and may not pay attention the requirement of the shareholders. The conflict could appear because the shareholders need to increase their wealth by increasing their shares, while agent might not always act as the principals want. There is a separation function between owners and managers hence they have different needs and objectives that will induce conflicts of interest.

A greater commitment of transparency in the company reports of their activities, it is believed that agency conflict can be minimized. Implementing GCG and CSR is a kind of ways to mitigate agency conflict between companies and stakeholders, particullary in the responsibility principle. CSR is closely relates to the principle of responsibility. The company is not only concerned with the continuity of the company on the interests of shareholders however with the implementation of GCG principles of responsibility; the company must also pay attention to the interests of stakeholders. CSR policies provide benefits to not only companies, but also to communities and environment.

Legitimacy theory placed the public as its responsibility. Lindblom (1994) mentioned that disclosing information about their social and environmental performance is a path for companies to maintain or regain their legitimacy in the society point of view. Legitimacy issue on the community is a strategic way for company in order to develop the company in the future. It can be used as a vehicle to construct corporate strategy, 
especially related to efforts to position themselves in an increasingly advanced society era.

The legitimacy of the organization can be seen as something the company wants or sought from society. Finally, legitimacy is a benefit or potential resource for company to survive (going concern). As a system of putting forward the alignment to the society, the operations of the company must be congruent with the expectations of community.

At last, according to Mousa and Hassan (2015), legitimacy theory is almost be used by researcher for explaining companies' behavior on environment and society, and also the motivation of company to act corporate social responsibility activities.

A company is not only seeking profit, but also trying to maintain its business sustainability in the future. The survival of a company is no longer due to being the ability of the owner or manager, but it is determined by many parties who cannot be ignored, such as: customers, employees, suppliers, creditors, management, government and others, which called stakeholders. Stakeholders also have interests of the company, and determine the sustainability of the company. This is mentioned in the stakeholders theory that companies should give attention to both shareholders and stakeholders. Furthermore, the stakeholders are a key factor for the success of the CSR practices. Without their engagement, knowledge, skills, talent, loyalty, the companies could not achieve its objectives.

The better CSR activities done by companies, this will give a positive impact to stakeholders' perception. Therefore, the community will fully support the company activities for achieveing their aims namely improving performance, achieving company profit and having long term sustainablity. Conversely, Aryani (2016) stated, stakeholders could make a harm the sustainability of the firm when they are disappointed and do not trust the firm anymore. Therefore, a company should either know what the stakeholders need or build a good relationship and communication with stakeholders in order to ensure the survival of the firm. Furthermore, Farook, 
Hassan, and Lanis (2011) adduce that entrepreneur or investment manager as mudarib in sharia bank has a significant effect on CSR disclosure. Along with that, doing CSR could be a good strategy for companies to maintain the relationship between company and stakeholders.

Entity theory focuses only to satisfy the shareholders, hence the company activities only directed to meet the welfare of the owners. Meanwhile, the concept of enterprise theory recognizes the responsibility not only to the owners of the company but also to the broader stakeholder groups. Therefore, implementation of enterprises theory is broader than entity theory.

Allah advises humans as caliph on earth in order to maintain the sustainability of natural resources and environment. When running a business whether directly or indirectly related to nature, human or company must pay attention and keep the condition of nature and environment included community in its surrounding. This means that environment, nature and humans are crucial for company in surviving in the future.

Concerning to stakeholders becomes very important for companies, so far companies are more concerned with a horizontal relationship between company, shareholders, stakeholders, and environment or nature. However, Triyuwono (2007) states that beside of those horizontal parties, there is the highest party and become the sole purpose of human life, that is Allah SWT, and this is as a form of vertical relationship. The broader vertical and horizontal relationships are mentioned in the Sharia Enterprise Theory (SET). In addition, Al Baqarah [2]: 205 and Al-Araaf [7]: 56 asserted that Allah Almighty advises human beings as the caliph in the earth to maintain the trust (natural resources) that $\mathrm{He}$ created and gave. So that in running business either directly related to nature or not, man must still pay attention to the condition of nature and environment wherever He is.

Sharia Enterprise Theory is a part of enterprise theory combining with Islamic value. Meutia (2009); Triyuwono (2007) asserted that there are three part of stakeholders, namely Allah SWT; human; and nature. The first 
stakeholder is placed God as the highest stakeholder and the creator of all things. By this, it will ensure that the construction of sharia accounting will be based on sunatullah, and subject to the rules or laws of God. The second stakeholder of SET is human, which is differentiated between directstakeholders and indirect-stakeholders. Direct-stakeholders are those who directly contribute to the company, both in the form of financial contributions and non-financial. Due to contributing to the company, they have a right to obtain a welfare from the company. Meanwhile, indirect-stakeholders are a parties that do not contribute financially and non-finance to the company, but in sharia context they are the parties who also have a right to achieve a welfare from company. The last stakeholder of SET is nature. Nature is a party that also contributes to the sustainability of company. Companies use energy that is dispersed in nature, such as producing their product by using raw materials from nature, providing services by utilizing energy which available in nature, and others. The nature does not want the welfare distribution in the form of money as humans want, however it needs company's concern in the conservation of nature, prevention of pollution, and others.

Finally, agency theory only adduced two parties namely agents (companies) and principals (stakeholders) such as investors, employees, debtors, suppliers. The agency theory only consider about human relationship, meanwhile legitimacy theory only pay more attention in responsibility to public such as act to environment and society which is categorized as horizontal party. The agency theory, stakeholder theory, and legitimacy theory do not consider Allah (God) which also part of stakeholders. As mentioned by Triyuwono (2007), companies have to pay attention vertical party that is Allah as the highest party and become the sole purpose of human life. Finally, relationship between human and Allah, human and human, human and environment cannot be separated.

Maier (2005:2) suggested a broader definition of CG is "Corporate governance defines a set of relationships between a company's management, 
its board, its shareholders and its stakeholders. It is the process by which directors and auditors manage their responsibilities towards shareholders and wider company stakeholders. For shareholders it can provide increased confidence of an equitable return on their investment. For company stakeholders it can provide an assurance that the company manages its impact on society and the environment in a responsible manner".

Five principles which must be implemented in CG are Transparency, Accountability, Responsibility, Integrity, and Fairness. Transparency means that firms have to reveal their information completely, accurately and in a timely manner to stakeholders. Transparency helps to avoid conflicts of interest. Meanwhile, accountability means that companies clearly defined roles and tasks and describes the firm's responsibility to manage its organisation effectively. This principle leads to a checks and balances mechanism of rules and authority in company's management. Furthermore, responsibility means that company compliance by management with legislation and adherence to sound companies' management principles. Independence means that companies must be managed in a professional manner without any influence or pressure from any parties. Finally, independence is very important in the decision making process; independence helps to ensure objectivity in making decisions, wherein the company's interests should be given the highest priority.

The definition of Corporate Social Responsibility (CSR) based in Republic of Indonesia Company Law No. 40 Year 2007 about corporation is a company commitment to involve in continuously economic development to increase the quality of life and useful environment both community and company. Meanwhile, the European Commission (2011: 4) defines corporate social responsibility as "a concept whereby companies integrate social and environmental concerns in their business operations and in their interaction with their stakeholders on a voluntary basis". Meanwhile CSR is defined by Lord Holme and Richard Watts (2010) that "The continuing commitment by business to behave ethically and contribute to economic development while 
improving the quality of life of the workforce and their families as well as of the local community and society at large".

Previous researchers have done to test the association between CG, ROE, size and CSR, however this study will employ sharia enterprise theory in the implementation of CSR. Implementing CG is concerned with combining to achieve economic and social purposes, as well as to fulfil individuals, companies or society interests. This means that CG will in line with CSR. Commissioner board is one of important elements in the CG mechanism. The commissioner will supervise the directors when they run its business. Dewi and Rahmawati (2010) found that there is a positive association between size commissioner board and CSR. Thereby, it is generally believed that independent outside directors will strengthen the board by monitoring the activities of the management, and ensure that interests of the investors are protected (Petra, 2005). Audit committee will clarify what the finding and what the directors have done in the operational of the company. A company which has a good audit committee, it will have more transparent and responsible to the stakeholders, and finally it has a positive correlation with CSR Badjuri (2011). Meanwhile, Mackenzie (2007) reported that corporate boards have a positive impact on CSR. Based on stakeholder theory, economic performance will support a company to implement CSR. Ebiringa, Yadirichukwu, Chigbu, and Ogochukwu (2013) found that profitability positively affect CSR. When companies have a high profit, it means the companies have economic ability to encourage to do CSR. Aryani (2012) asserted that GCG through ROE affected CSR. Moreover, Blombäck and Wigren (2008) argued that company size has a positive relationship with CSR activities. Farooq et al. (2015) added that large firms which have more resources will be more capable and flexible to use their funds for doing CSR. Maryanti and Tjahjadi (2013) found that CSR and GCG affect ROE, meanwhile GCG influenced CSR, and size moderates the correlation between CSR and ROE. Meanwhile, Trencansky and Tsaparlidis 
(2014) asserted that CSR activities is affected by firm size, however the effect is more tend to $\mathrm{U}$ shaped pattern. Along with that, the hypotheses are:

Hypothesis 1: GCG and ROE with size as moderating variable affect CSR

Hypothesis 2: there is a positive effect of GCG, ROE and size on CSR

\section{Method}

This research consist of 10 sharia banks in Indonesia which reported their CG and CSR activities above the year 2014 to 2016, namely BNI Sharia, Mega Sharia, Muamalat Indonesia, Sharia Mandiri, BCA Sharia; BRI Sharia, Jabar Banten Sharia, Panin Sharia, Bukopin Sharia, and Maybank Sharia Indonesia. This study employs a quantitative methodology with statistic test i.e. multiple regression for examining the impact of CG and ROE on CSR with size as moderating variable. This study uses pooled data therefor the model Common Effect model will be employed, because the Common Effect (Pooled Least Square) model is the simplest model and the study did not use dummy variable. Moreover, the model neglects individual and time dimension, and it is assumed that the behavior of data will be not differ in various periods.

Corporate governance will be proxy by commissioner board size, number of audit committee meeting; Number of Nomination and Remuneration Committee Meetings, number of directors. Size is proxy by total assets. Return on Equity (ROE) is employed for proxy of profit. For measuring sharia CSR implementation, this study adopts Meutia (2009)'s method that consider SET. There are 21 items in SET activities as shown in table 1. Meutia (2009) sets score $1=$ if the company does one of the 21 items of SET, conversely score 0 if they do not explain the item. Score of SET is measured by number of implementation of SET divided by total score of SET (21 items). 
Table 1. Item of Sharia Enterprise Theory

\begin{tabular}{lc}
\hline \multicolumn{1}{c}{ Item of SET } & Score \\
\hline 1.Vertical accountability i.e to Allah SWT & 1 \\
A. There is opinion from Sharia Supervisory Board & 1 \\
B. The obeyed and disobeyed fatwa of operational aspects reports & \\
2. Horizontal accountability (direct stakeholders) & 1 \\
A. Qualifications and experiences of members of sharia supervisory board reports. & 1 \\
B. Zakat and qardhul hasan reports & 1 \\
C. Information of sharia products and concept of sharia & 1 \\
D. Number of financing & 1 \\
E. Explanation about policy on non sharia activities / transactions & 1 \\
3. Horizontal accountability (direct stakeholders) i.e to staff & 1 \\
A. Report of salary and remuneration policy & 1 \\
B. Policy about training for enhancing staff quality & 1 \\
C. Availability of health services for staff & \\
D. Other facilities for staff's family such as scholarship and special funding & 1 \\
4. Horizontal accountability (indirect stakeholders) i.e communities & 1 \\
A. Report of initiatives to enhance public access on Islamic financial services \\
B. Policy of financing with consideration on discrimination and human right \\
C. Policy of financing with consideration on public interests. \\
D. Contribution on fields namely religious, education and health in order to
\end{tabular}

Source: Meutia (2009)

Based on the hypotheses above, the regression model are:

Model $1: \mathrm{CSR}=\alpha+\beta 1 \mathrm{GCG}+\beta 2 \mathrm{ROE}+\beta 3$ SIZE $\times \mathrm{GCG}+\beta 4 \mathrm{SIZE} \times \mathrm{ROE}$

Model $2: \mathrm{CSR}=\alpha+\beta 1 \mathrm{GCG}+\beta 2 \mathrm{ROE}+\beta 3 \mathrm{SIZE}$

\section{Result and Discussion}

The effect of independent variables (GCG, ROE) on CSR as dependent variable with size as moderating variable were tested by regression analysis, however, this study had tested the underlying assumptions in the regression model for multicollinearity based on the correlation matrix as well as the variance inflation factor (VIF). Moreover, central limit theorem mentioned that if number of sample is $\geq 30$, it is considered sufficient and means that the distribution of the sample is fairly normally distributed.

Table 2 shows that the average of CSR based on SET is 0.7027 less than 1. This means that several banks have not completed to employ CSR based on SET. It can be proven that the minimum score of SET is 0.52 while the 
maximum score is 1 . In addition, the minimum score on the items of number of audit meeting and number of meeting of numeration are zero, it shown that there is a bank did not held audit and numeration meeting. This is in line with Farook and Lanis (2007) who mentioned that only few of Islamic banks and financial institutions have paid attention on social activities. Maali, Casson, and Napier (2006) also asserted that sharia banks carry out CSR because of incentive motivation and just want to run Islamic activities.

Table 2. Statistics of Variables

\begin{tabular}{lccccccc}
\hline \multicolumn{1}{c}{$\mathrm{N}=30$} & ROE & SIZE & $\begin{array}{c}\text { NMB } \\
\text { COMM }\end{array}$ & $\begin{array}{c}\text { MEET } \\
\text { AUDIT }\end{array}$ & $\begin{array}{c}\text { MEET } \\
\text { COMNUM }\end{array}$ & $\begin{array}{c}\text { NMBR } \\
\text { DIR }\end{array}$ & SET \\
\hline Mean & .02479 & 19.178 & 3.633 & 11.033 & 4.667 & 4.633 & .7027 \\
Std. Deviation & .14932 & 24.417 & 1.098 & 7.049 & 2.869 & 1.273 & .1067 \\
Minimum & -.4905 & 1.34 & 2.00 & .00 & .00 & 3.00 & .52 \\
Maximum & .3171 & 78.83 & 6.00 & 31.00 & 11.00 & 7.00 & 1.00 \\
\hline \multicolumn{7}{c}{ Source: SPSS }
\end{tabular}

When model 1, GCG, ROE and size as moderating variable affect CSR was tested, the result indicated a multicollinearity, hence $\beta$ ROE.size was excluded. However, the statistic test in table 3 generates that size could not moderate the effect of GCG and ROE on CSR. This indicated that size is not fit as a moderating variable for testing the effect of GCG and ROE on CSR, therefore Hypothesis 1 is rejected.

Consistent with Farook et al. (2011) who employed size as a control variable, however the result determined that size was able to predict direction but it does not have significant correlation with CSR.

Due to having insignificant moderating effect on CSR, then size was entered in the model as independent variable aggregately with ROE and GCG as written in model 2.

When partially ROE, CG, size and CSR are tested, the data in table 4 demonstrated that only size has a positive significant correlation with CSR. Meanwhile statistical test exhibits that partially variable of GCG namely number of commissioners; number of audit meeting; number of remuneration meeting and number of directors and ROE did not have correlation with CSR. 
It is supported by Benomran et al. (2015) who concluded that corporate government has insignificant correlationship with CSR in Libyan companies. This is in line with Nawaiseh (2015) Mozghovyi and Ratnykova (2011) who found that ROE did not affect CSR. Therefore, sharia banks did not held CSR activities based on their profit, thereby, other factors affect banks to do CSR. This condition suggests that implementation of SET or CSR activities did not depend on profit. In other word that profitability is not a main reason for sharia banks to do CSR and even though banks have a high profit, they may not keen to do CSR. This can be conclude that sharia banks did CSR not just because of a high profit, but it might they consider other reasons namely voluntary activities, regulations, or a kind of promotion. Nevertheless, this study contradict with Hussainey, Elsayed, and Razik (2011) who argued that profitability support companies to implement CSR. This is plausible because as sharia banks they have religious value that they help not only environment, and nature but also social and human based on obligatory to help society not based on merely profit. However, when ROE and CG simultaneously are combined and tested toward CSR, the results exhibited that ROE and CG significantly affect CSR by F (3.879) and adjusted R square was 33.2\%. This result consistent with Novianti (2017) who found that GCG together with ROE influenced CSR. The result is also in line with Aryani (2012) who asserted that GCG through ROE affected CSR.

Corroborating with Farooq et al. (2015), partially there is a positive relationship between size and CSR as shown the result in table 4 . This means that a large firm will have more resources to implement CSR. While, table 4 also presents that connection between corporate governance and corporate social responsibility practices is insignificant. This is not agree with Farooq et al. (2015) and Harjoto and Garen (2005) who mentioned that GCG has a positive and significant impact on CSR. On the other hand, this research consistent with Chintrakarn, Jiraporn, Kim, and Kim (2016) who ascertained that a company with good quality of CG will reduce the investment in CSR. 
Finally, having a good corporate governance did not assure to drive sharia banks to conduct CSR.

Table 3. The Result of The Relationship between GCG, ROE and Size as Moderating Variable on CSR

\begin{tabular}{lcrrrr}
\hline \multicolumn{1}{c}{ Model } & Standardized Coefficients Beta & $\mathrm{t}$ & Sig. & Tolerance & VIF \\
\hline (Constant) & & 6.801 & .000 & & \\
ROE & .390 & 1.460 & .161 & .264 & 3.793 \\
NMBCOMM & -.161 & -.430 & .672 & .135 & 7.428 \\
MEETAUD & -.051 & -.125 & .902 & .115 & 8.687 \\
MEETCOMM & .100 & .415 & .683 & .327 & 3.063 \\
NMBRDIR & -.225 & -.859 & .401 & .273 & 3.657 \\
nnbcom_size & .151 & .159 & .875 & .021 & 47.823 \\
meeaud_size & .180 & .289 & .776 & .049 & 20.612 \\
meetcom_size & .807 & 1.199 & .245 & .042 & 24.029 \\
nmbrdir_size & -.066 & -.067 & .947 & .020 & 50.017 \\
roe_size & -.207 & -.532 & .601 & .124 & 8.061 \\
\hline
\end{tabular}

Source: SPSS

Table 4. The Statistic Result of The Relationship between GCG, ROE, Size, and CSR

\begin{tabular}{lcrrrr}
\hline \multicolumn{1}{c}{ Model } & $\begin{array}{c}\text { Standardized Coefficients } \\
\text { Beta }\end{array}$ & T & Sig. & Tolerance & VIF \\
\hline (Constant) & 0.283 & 7.192 & .000 & & \\
ROE & 0.749 & 2.055 & .051 & 0.950 & 1.052 \\
SIZE & -0.254 & 2.775 & .011 & 0.248 & 4.040 \\
NMBCOMM & 0.104 & -1.209 & .239 & 0.408 & 2.451 \\
MEETAUD & 0.259 & 0.551 & .587 & 0.505 & 1.981 \\
MEETCOMM & -0.152 & 1.609 & .121 & 0.694 & 1.441 \\
NMBRDIR & \multicolumn{5}{c}{ Source: SPSS } \\
\hline \multicolumn{5}{c}{} \\
\hline
\end{tabular}

Source: SPSS

Interestingly, by entering size in the model of examination between GCG and ROE aggregately on CSR (model 2), the result exhibited that adjusted $\mathrm{R}$ square increased form 0.453 to 0.478 and $\mathrm{F}=5.419$. Empirical research reveals that there is a significant positive impact of GCG and ROE simultaneously with size on CSR. This means that size of company is a strong factor induces sharia banks to conduct CSR based on the SET. However, this results contradict with Hussainey et al. (2011) who argued that size did not drive CSR. By contrast, this is agree with Farooq et al. (2015); Furtado et al. 
(2016) who argue that size and CSR has a positive relationship. A big company will have more stakeholders, strong financial and more sensitive to be monitored by public who concern on environment than small firm, hence sharia banks with high assets do more sharia CSR activities.

The adjusted R2 of the relationship between GCG, ROE and firm size on CSR is 0.478 , this adduce that $47.8 \%$ of CSR is determined by GCG, ROE and size, meanwhile the rest is affected by other factors. Nawaiseh (2015) suggests that another factor that able to affect banks to implement CSR is regulations due to all limited liabilities companies having an obligation to perform CSR. Moreover, Farook and Lanis (2007) found that existence of Sharia Supervisory Board is also a factor to drive sharia banks to employ CSR. A greater member of supervisory board, may induce a greater compliance of CSR implementation. Furthermore, Farook et al. (2011) argued that CSR implementation in Islamic banks can be affected by socio-political pressures and economic incentives. A number of Sharia Supervisory Board member could make CSR monitor mechanism will be more scrupulous particularly in sharia laws and principles compliance.

The result of this research is in line with agency theory. By implementing of CSR, companies have a good relationship with stakeholders and it could minimize agency conflict. In addition, the positive effect of GCG, ROE and size on CSR means that based on stakeholders theory, Islamic banks which implement corporate government consider to fulfill the stakeholders' wealth by doing CSR for social concern. The statistic exhibits when a large and profitable sharia bank which apply good corporate governance, the implementation of CSR tend to be higher. This shows that large sharia banks with good corporate governance supported by high-profit, will be more concern to implement CSR based on sharia consideration.

\section{Conclusion}

Even though all the sharia banks have done CSR and in line with enterprise theory, the sharia banks have not fully implemented CSR based on 
SET. They might do CSR because many reasons, such as regulations, monitored by supervisory board, incentive motivation, socio-political pressures, and economic incentives or just for promotion.

Implementing a good corporate governance which is determined by number of commissioner board, number of audit meeting, number of numeration meeting and number of director influences sharia banks to act CSR, however profit (ROE) did not induce sharia banks to implement CSR. The statistic tests generate results that simultaneously GCG and ROE affect CSR. Attractively, the involvement of size simultaneously with GCG and ROE induces the effect on implementation of CSR stronger. The result supports agency theory and this condition mitigates agency conflict between banks (agents) and stakeholders (principals). Hypothesis 2 mentioned that there is a positive effect of GCG, ROE and size on CSR aggregately is accepted.

Accordingly, the independent variables namely GCG, ROE, and firm size simultaneously affect CSR activities based on SET on sharia banks in Indonesia. Therefore, the statistical model number 2 is fit to predict factors influence CSR, namely GCG, ROE and size. Even though the result is in line with agency theory, and CSR activities could reduce conflict between communities and banks, the CSR activities should consider vertical party, Allah. Furthermore, considering stakeholder theory, sharia banks should act CSR not only for horizontal direction but also vertical direction namely Vertical Accountability, to Allah SWT; Horizontal accountability (direct stakeholders); Horizontal accountability (direct stakeholders) i.e. to staff, and Horizontal accountability (indirect stakeholders) i.e. communities (Meutia, 2009).

This research has some implications namely first, on enriching agency theory and the determinants affect CSR in sharia banking. Second, the results also contribute on Entity theory and Enterprise theory particularly in implementation CSR based on sharia value. Nevertheless, this study has a limitation due to the number of sample was very small. Along with that it will be better for further researcher should employ more number of sharia banks. 
Besides, the items of sharia enterprise theory was very simple, in the next research it supposes that SET will be explained in more detail particularly in the vertical accountability.

\section{References}

Aryani, D. (2012). Kajian Kinerja Keuangan dan Corporate Social Responsibility Terhadap Good Corporate Governance dan Nilai Perusahaan. Paper presented at the Seminar Nasional dan Call for Papers, Universitas Stikubank Semarang.

Badjuri, A. (2011). Faktor-Faktor Fundamental, Mekanisme Coorporate Governance, Pengungkapan Coorporate Social Responsibility (CSR) Perusahaan Manufaktur Dan Sumber Daya Alam Di Indonesia. Dinamika Keuangan dan Perbankan, Vol. 3(1): 38 - 54.

Benomran, N., et al. (2015). Influence of Corporate Governance on the Extent of Corporate Social Responsibility and Environmental Reporting. Journal of Environment and Ecology, Vol. 6(1): 48-68.

Blombäck, A., and Wigren, C. (2008). Challenging the Importance of Size as Determinant for CSR Activities. Management of Environmental Quality: An International Journal, Vol. 20(3): 255 - 270.

Chintrakarn, P., et al. (2016). The Effect of Corporate Governance on Corporate Social Responsibility. Journal of Financial Studies, Vol. 45(1).

Dewi, U. I., and Rahmawati. (2010). Pengaruh Ukuran Perusahaan, Ukuran Dewan Komisaris, Kepemilikan Institusional, Kepemilikan Asing, dan Umur Perusahaan terhadap Corporate Social Responsibility Disclousure pada Perusahaan Property dan Real Estate yang Terdaftar di Bursa Efek Indonesia. Jurnal Akuntansi dan Manajemen, Vol. 21(3): 297-306.

Ebiringa, O. T., et al. (2013). Effect of Firm Size and Profitability on Corporate Social Disclosures: The Nigerian Oil and Gas sector in Focus. British Journal of Economics, Management and Trade, Vol. 3(4): 563-574.

Erwanda, E., and Mulawarman, A. D. (2012). Tanggung Jawab Sosial Pada Organisasi Perbankan Syariah (Studi Kasus Pada Bni Syariah Cabang Malang). Jurnal Ilmiah FEB, Universitas Brawijaya, Vol. 1 (2).

Farook, S., Hassan, M. K., and Lanis, R. (2011). Determinants of Corporate Social Responsibility Disclosure: The Case of Islamic Banks. Journal of Islamic Accounting and Business Research, Vol. 2(2): 114-141.

Farook, S., and Lanis, R. (2007). Banking on Islam? Determinants of Corporate Social Responsibility Disclosure. School of Accounting. University of Technology, Sydney. 
Farooq, S. U., Ullah, S., and Kimani, D. (2015). The Relationship between Corporate Governance and Corporate Social Responsibility (CSR) Disclosure: Evidence from the USA. Abasyn Journal of Social Sciences, Vol. 8(2): 197-212.

Furtado, T., Araújo, R., and Moreira, R. d. L. (2016). Relationship Between Corporate Governance And Corporate Social Responsibility Disclosure In Brazilian Companies. Paper presented at the XXI Congreso Internacional de Contaduria, Administracion E Informatica.

Harjoto, M., and Garen, J. (2005). Inside Ownership Beyond The IPO: The Evolution of Corporate Ownership Concentration. Journal of Corporate Finance, Vol. 11(4): 661-679.

Hussainey, K., Elsayed, M., and Razik, M. A. (2011). Factors Affecting Corporate Social Responsibility Disclosure In Egypt. Corporate Ownership and Control, Vol. 8(4).

Jensen, M. C., and Meckling, W. H. (1976). Theory of The Firm: Managerial Behavior, Agency Costs and Ownership Structure. Journal of Financial Economics, Vol. 3(4): 305-360.

Jo, H., and Harjoto, M. A. (2011). Corporate Governance and Firm Value: The Impact of Corporate Social Responsibility. Journal of Business Ethics, Vol. 103: 351-383.

Khan, A., Muttakin, M. B., and Siddiqui, J. (2013). Corporate Governance and Corporate Social Responsibility Disclosures: Evidence from an Emerging Economy. Journal Business Ethics, Vol. 114: 207-223.

Lindblom, C. K. (1994). The Implications of Organizational Legitimacy for Corporate Social Performance and Disclosure. Paper presented at the Critical Perspectives on Accounting Conference, New York.

Maali, B., Casson, P., and Napier, C. (2006). Social Reporting by Islamic Banks. Abacus, Vol. 42 (2).

Mackenzie, C. (2007). Boards, Incentives and Corporate Responsibility: The Case for a Change of Emphasis. Corporate Governance. An International Review, Vol. 15: 935-943.

Mansur, S. (2012). Pelaporan Corporate Social Responsibility Perbankan Syariah dalam Perspektif Syariah Enterprise Theory (Studi Kasus pada Laporan Tahunan PT Syariah Mandiri). Universitas Hasanuddin, Makasar.

Maryanti, E., and Tjahjadi, B. (2013). Analisis Corporate Social Responsibility dan Good Corporate Governance Terhadap Kinerja Keuangan yang Mempengaruhi Nilai Perusahaan Manufaktur yang Terdaftar di Bursa Efek Indonesia. Jurnal Ekonomi dan Bisnis, Tahun XXIII, (1): 47-62.

Meutia, I. (2009). Shari'ah Enterprise Theory Sebagai Dasar Pengungkapan Tanggungjawab Sosial Bank Syariah. Universitas Brawijaya Malang. 
Meutia, I., and Febrianti, D. (2017). Islamic Social Reporting in Islamic Banking: Stakeholders Theory Perspective. Paper presented at the SHS Web of Conferences 34 .

Mousa, G. A., and Hassan, N. T. (2015). Legitimacy Theory and Environmental Practices: Short Notes. International Journal of Business and Statistical Analysis, Vol. 2(1).

Mozghovyi, Y., and Ratnykova, I. (2011). Correlation Between The Corporate Social Responsibility and Financial Perfomance of The Bank in Ukrainian Context. Paper presented at The Second Annual Online International Conference on Corporate Governance and Regulation in Banks, Sumy, Ukraine.

Nawaiseh, M. E. (2015). Do Firm Size and Financial Performance Affect Corporate Social Responsibility Disclosure: Employees' and Environmental Dimensions? American Journal of Applied Sciences, Vol. 12(12): 967-981.

Novianti. (2017). Pengaruh Good Corporate Governance dan Profitabilitas Terhadap Pengungkapan Corporate Social Responsibility (Studi pada Perusahaan $S$ Ektor Pertambangan Peserta CGPI (Corporate Governance Perception Index ) yang Terdaftar di Bursa Efek Indonesia Periode 2009 - 2016). Universitas Pasundan Bandung.

Petra, S. T. (2005). Do Outside Independent Directors Strengthen Corporate Boards. Corporate Governance, Vol 5(1): 55-64.

Trencansky, D., and Tsaparlidis, D. (2014). The Effects of Company's Age, Size and Type of Industry on The Level of CSR : The Development of a New Scale for Measurement of The Level of CSR. (master), Umeå univesity.

Triyuwono, I. (2007). Mengangkat "Sing Liyan" untuk Formulasi Nilai Tambah Syari"ah. Paper presented at the Simposium Nasional Akuntansi X Universitas Hasanudin, Makasar.

Wiroso. (2009). Produk Perbankan Syariah. Jakarta: LPFE Usakti. 